NBER WORKING PAPER SERIES

\title{
VALUING A HOMELAND SECURITY POLICY: COUNTERMEASURES FOR THE THREATS FROM SHOULDER MOUNTED MISSILES
}

\author{
V. Kerry Smith \\ Carol Mansfield \\ Laurel Clayton \\ Working Paper 14325 \\ http://www.nber.org/papers/w14325 \\ NATIONAL BUREAU OF ECONOMIC RESEARCH \\ 1050 Massachusetts Avenue \\ Cambridge, MA 02138 \\ September 2008
}

Thanks are due Barbara Kanninen for assistance with the development of the experimental designs for the surveys, to Detlof von Winterfeldt and CREATE's Science Advisory Committee for comments on earlier versions of this research, to Eric Moore for excellent research assistance, and to Richard Laborin for assistance in preparing several drafts of this manuscript. The research was supported by the United States Department of Homeland Security through the Center for Risk and Economic Analysis of Terrorism Events (CREATE) under grant numbers 2007-ST-061-000001 and DE-AC05-76RL01830. However, any opinions, findings, and conclusions or recommendations in this document are those of the authors and do not necessarily reflect views of the United States Department of Homeland Security. The views expressed herein are those of the author(s) and do not necessarily reflect the views of the National Bureau of Economic Research.

NBER working papers are circulated for discussion and comment purposes. They have not been peerreviewed or been subject to the review by the NBER Board of Directors that accompanies official NBER publications.

(C) 2008 by V. Kerry Smith, Carol Mansfield, and Laurel Clayton. All rights reserved. Short sections of text, not to exceed two paragraphs, may be quoted without explicit permission provided that full credit, including $\odot$ notice, is given to the source. 
Valuing a Homeland Security Policy: Countermeasures for the Threats from Shoulder Mounted Missiles

V. Kerry Smith, Carol Mansfield, and Laurel Clayton

NBER Working Paper No. 14325

September 2008

JEL No. D61,H41,H56

\begin{abstract}
This paper reports estimates for the ex ante tradeoffs for three specific homeland security policies that all address a terrorist attack on commercial aircraft with shoulder mounted missiles. Our analysis focuses on the willingness to pay for anti-missile laser jamming countermeasures mounted on commercial aircraft compared with two other policies as well as the prospect of remaining with the status quo. Our findings are based a stated preference conjoint survey conducted in 2006 and administered to a sample from Knowledge Networks' national internet panel. The estimates range from $\$ 100$ to $\$ 220$ annually per household. Von Winterfeldt and O'Sullivan's [2006] analysis of the same laser jamming plan suggests that the countermeasures would be preferred if economic losses are above $\$ 74$ billion, the probability of attack is larger than 0.37 in ten years, and if the cost of the measures is less than about $\$ 14$ billion. Our results imply that, using the most conservative of our estimates, a program with a cost consistent with their thresholds would yield significant aggregate net benefits. More generally, this research grows out of a need to measure the benefits of an iconic public good -- national defense -- to assess the economic efficiency of Department of Homeland Security policies.
\end{abstract}

V. Kerry Smith

Department of Economics

W.P. Carey School of Business

P.O. Box 873806

Arizona State University

Tempe, AZ 85287-3806

and NBER

kerry.smith@asu.edu

Carol Mansfield

RTI International

3040 Cornwallis Rd.

PO Box 12194

Research Triangle Park, NC 27709

carolm@rti.org
Laurel Clayton

RTI International

3040 Cornwallis road

Research Triangle Park, N.C. 27709

lclayton@rti.org 


\title{
Valuing a Homeland Security Policy: Countermeasures for the Threats from Shoulder Mounted Missiles
}

\author{
V. Kerry Smith, Carol Mansfield, and Laurel Clayton*
}

\section{Introduction}

Threats to security have economic consequences. It is impossible to assess the full scope of the emotional loss to families affected by $9 / 11$. Many people around the world would no doubt suggest they also experienced tangible losses even though they did not have family or friends who were directly affected. These losses cannot be measured. But some economic impacts can be measured. Preliminary ex post assessments of the economic impacts of $9 / 11$, considering health effects (excluding mortality), damages to structures, ripple effects throughout the economy, and so forth suggest losses in the tens if not hundreds of billions of dollars. Nonetheless, there remains a potentially larger ex ante effect. Persistent terrorism risks have the potential to undermine public confidence in any society. Such a loss of confidence could result in significant changes in how people choose to live their lives and conduct their daily activities and all that might imply for the economies affected by terrorist threats. Before this large scale change would occur it is reasonable to expect that governments at all levels, households, and firms would undertake investments in security. In this country we have experienced a number of changes in regulations governing private activities. Air travel is certainly a notable example of an activity that has changed dramatically as a result of new security regulations. In addition people may also alter other aspects of their own daily activities and re-evaluate their household budget priorities. In principle, each of these actions has the potential to raise the transaction costs of daily living. We have little empirical evidence on the extent of these costs or what people would pay to protect key sectors from disruption due to terrorism. This paper offers the first empirical evidence on the public's monetary support for anti-terrorism measures. 
In previous work, some authors measured of the implications of terrorism for the pace and scale of economic activities. For example, Abadie and Gardeazabal [2003] found that terrorist conflicts had large effects on the Basque economy, reducing GDP per capita by ten percentage points relative to a synthetic control region without terrorism. Moreover, the direction of this estimated impact was confirmed by their evaluation of the stock performance of firms with a stake in this economy using the 1998-1999 Basque truce as a natural experiment. There have also been a number of other recent studies confirming both market responses and individual behavioral adjustments to threats of terrorist actions. $^{1}$

Many current homeland security policies focus on ex ante actions that reduce the risk of attacks or minimize the damage that can take place after particular types of attacks. Ideally, efforts to estimate the benefits of these policies would consider the ex ante trade-offs people would make in exchange for the specific ways in which security would be enhanced. Unfortunately, there appears to be very little economic research addressing these challenges ${ }^{2}$. When evaluations of new Department of Homeland Security (DHS) rules are undertaken (under Executive order 12866) benefits are difficult to quantify.

\footnotetext{
* W. P. Carey Professor of Economics, Arizona State University, University Fellow Resources for the Future, and Research Associate, National Bureau of Economic Research; Senior Economist, RTI International; and Research Assistant, RTI International, respectively. Thanks are due Barbara Kanninen for assistance with the development of the experimental designs for the surveys, to Detlof von Winterfeldt and CREATE's Science Advisory Committee for comments on earlier versions of this research, to Eric Moore for excellent research assistance, and to Richard Laborin for assistance in preparing several drafts of this manuscript. The research was supported by the United States Department of Homeland Security through the Center for Risk and Economic Analysis of Terrorism Events (CREATE) under grant numbers 2007-ST-061-000001 and DE-AC05-76RL01830. However, any opinions, findings, and conclusions or recommendations in this document are those of the authors and do not necessarily reflect views of the United States Department of Homeland Security.

${ }^{1}$ For example, Abadie and Dermisi [forthcoming] evaluated whether 9/11 changed the occupancy rates in commercial buildings around signature structures in Chicago ((i.e. the Sears Tower, the Aon Center, and the Hancock Center) and found it did have an impact. Zussman et. al. [2008] found that major escalations in violence in the Israeli-Palestinian conflict led to declines in asset prices. By contrast, Glaeser and Shapiro use evidence on wars and cities in the $20^{\text {th }}$ century to document that while wars can have substantial impacts on urban settings in the short term, they have not significantly altered urban form. Thus, they conclude terrorism is likely to have a small effect on U.S. cities.

${ }^{2}$ A notable exception is Viscusi and Zeckhauser's [2005] early survey of law students to assess their willingness to relinquish civil liberties for domestic security. In addition Sandler et al [2007] report a detailed benefit cost analysis of terrorism policy using measures of the value of a statistical life, estimates for the value of disability adjusted life years and GDP effects to measure benefits.
} 
Most studies focus on ex post estimates of damages. While there are certainly a number of features of homeland security policies that make them difficult to evaluate, one motivation for the research we report here is to gauge whether people are able to assess the resource commitments they would make for policy alternatives involving terrorist related actions. In addition to assuming people can make these choices we also hypothesize that individuals recognize there is uncertainty about whether the policies will actually be needed and whether they will be effective.

This paper reports estimates for the ex ante tradeoffs for three specific homeland security policies that all address a common threat -- a terrorist attack on commercial aircraft with shoulder mounted missiles (i.e. Man Portable Air Defense Systems or MANPADS). Our example focuses on the willingness to pay for anti-missile laser jamming countermeasures mounted on commercial aircraft compared with two other policies as well as the prospect of remaining with the status quo. Our findings, based a SP conjoint survey conducted in 2006 and administered to a sample from Knowledge Networks' national internet panel, indicate a statistically significant annual willingness to pay of $\$ 222$ per household for a program with laser jamming countermeasures. The results also suggest robust support for this program that is larger for higher income households and is maintained regardless of whether an increased gasoline tax or income tax is used as the payment vehicle described for the program. Other cross checks of our survey indicate frequent fliers have greater support for some actions and that those who do not support the program feel the threat is not serious.

The paper proceeds as follows. Section II describes the rationale for these counter measures and outlines a simple choice model for the laser jamming missile defense system and two other programs to protect commercial aircraft from MANPADS. Section III discusses the stated choice conjoint questions, the details associated with implementing the survey, and the characteristics of the sample. The findings are presented in Section IV and the last section summarizes the results and comments on 
the relevance of these types of studies for the evaluation of DHS rules as part of the benefit-cost analyses required for major rules.

\section{Problem Context and Choice Model}

\section{A. Problem Context}

National defense has served for over fifty years of public economics and public finance as a signature example of a pure public good. Over thirty years ago, Samuelson [1976] used the example in the tenth edition of his text. His description would aptly fit the case of homeland security today:

"Nothing is more vital to a threatened society than its security. But national defense, regarded as a commodity, differs completely from the case of a private commodity like bread...national defense has to be provided more or less automatically for all” (p. 159).

While few would debate the public good status of national defense or homeland security, most analysts would also argue that the very features that convey this pure public status also make it difficult to describe and quantify "amounts" of national defense. As a result, there have been few efforts to measure citizen's willingness to pay for more national defense. Indeed, early writers in benefit-cost methods suggested the same was true for most public goods, concluding that policy decisions had to be derived from a political process. ${ }^{3}$

The experience with stated preference (or SP) methods applied to estimate the economic tradeoffs people would make for policies that improve environmental resources, particularly over the past eighteen years, has provided direct evidence that we can measure the value of some public goods. ${ }^{4}$ There is now a broader acceptance that SP methods, designed using documented protocols for

\footnotetext{
${ }^{3}$ Eckstein's [1961] early and classic treatise on benefit cost methods for water investments noted that efforts to estimate economic values for the public and non-market private goods provided by these projects would ultimately discredit the methodology. See Smith [1996] for further discussion.

${ }^{4}$ This conclusion is not uniformly shared by economists in general. Despite considerable progress in SP methods, many economists continue to cite Diamond and Hausman's [1994] critical judgment on the plausibility of contingent valuation. See Carson and Hanemann [2005] for a more up-to-date summary by authors who have been favorable in their assessments of SP methods.
} 
questionnaire design, can measure the public's willingness to pay for a change in the quantity or quality of many different types of public goods ${ }^{5}$. A key ingredient for the success of SP strategies has been the use of specific plans to improve or avoid declines in the quality or amounts of the environmental services being studied. ${ }^{6}$ We adopt this same strategy for our evaluation of people's willingness to pay for homeland security. As discussed in the introduction, efforts to estimate economic tradeoffs people would make for the outcomes of DHS policies ("improved security") independent of the plan for achieving the improved security are unlikely to provide reliable measure of the policy's benefits as measured by aggregate willingness to pay. Our survey describes specific plans to protect commercial aircraft and, as a result, the tradeoffs we measure from the SP conjoint survey relate to these specific plans, not improvements in homeland security in general. This specificity is essential to making the objects of choice salient and to convincing respondents that their stated choices will be consequential (Landry and List [2006]).

\section{B. Modeling the Choice of Homeland Security Plans}

In January 2008, DHS announced it would spend \$29 million on tests of an anti-missile laser jamming system for commercial airliners with three American Airlines Boeing 767-200s that fly daily round trips between New York and California. ${ }^{7}$ The threat of attacks from such systems has been widely acknowledged since at least 2001 with estimates of 4,000 to 5,000 heat-seeking missiles accessible to anti-Western terrorist organizations (Bolkom and Ellias [2006]).

While the threat of an attack on a commercial airline is real, the probability a typical person, even a frequent air traveler, would be involved in a terrorist attack is extremely small with or without

\footnotetext{
${ }^{5}$ As with revealed preference methods there are no guarantees that SP methods will always work. Instead what the literature has focused on is a series of robustness checks to identify strategies that are likely to be unreliable. See Smith [2007] for further discussion.

${ }^{6} \mathrm{~A}$ key distinction in the work since the Exxon Valdez SP assessment undertaken in 1991 and published much later in Carson et. al. [2003] has been the use of specific plans describing how changes in non-market resources would be undertaken. See Smith [1997] for a discussion of the implications of the use of plans for the interpretation of SP estimates of economic tradeoffs. This strategy does not as a rule attempt to measure the amount of the nonmarket good that is delivered by the plan involved.

${ }^{7}$ See Hall [2008] for a newspaper account summarizing the pilot program.
} 
public countermeasures (see Becker and Rubenstein [2004] for a similar argument about terrorist activities in Israel). What is at issue is protecting the commercial airline system as a key part of the U.S. transportation infrastructure and maintaining public confidence in the airline system. The importance of this protection has been documented in several studies conducted after 9/11. Balvanyos and Lave [2005] estimated the consumer surplus loss from an air travel shutdown at as much as \$2 billion per day. Alternative estimates of the economic impact of shutdown using input-output analysis range from \$14.2 to $\$ 43$ billion for a year (Santos and Haimes [2004]) to $\$ 214$ to $\$ 420$ billion for a seven day shutdown of the entire U.S. commercial air transportation system followed by a two year recovery (Gordon et al $[2007])^{8}$

To estimate the public's willingness to pay to reduce the probability of a successful missile attack and the associated economic and social disruption, we designed a conjoint survey (also known as a discrete choice experiment). An SP conjoint survey is a systematic, survey-based, method for measuring individuals' tradeoffs. The conjoint method is based on the hedonic principle that goods and services are composed of a set of features or attributes and that the utility obtained from a particular good is a function of these attributes. Conjoint questions elicit respondents' choices among a finite set of alternatives (see Kaninnen [2007] or Hensher, Rose, and Greene [2005] for a description of conjoint analysis). Conjoint data yield quantitative estimates of the marginal rates of substitution among attributes.

The conjoint survey presented survey respondents with security plans to protect commercial aircraft that have different features and costs, described in Section III. In our application, each choice question presented respondents with two plans and a "no-plan" status quo or baseline option. Each respondent answered two choice questions, which are described as two independent situations. The structure yields a panel with answers to two choices for each respondent consistent with a random

\footnotetext{
${ }^{8}$ The Santos and Haimes analysis involved a 10\% shutdown of the US air transport system over a year.
} 
utility model (RUM). The respondents' decisions can be described with a random utility model as given in equation (1).

$V_{i j}=v\left(y_{i}-c_{i j}, \bar{A}_{j}, \bar{A}_{j} \cdot \bar{Z}_{i}\right)+\varepsilon_{i j}$

$V_{i j}$ designates the utility individual i realizes from selecting plan $j ; y_{i}$ designates income from individual $i$;

$\mathrm{c}_{\mathrm{ij}}$ corresponds to the cost presented to individual i for plan j; $\bar{A}_{j}$ represents a vector of attributes for

plan j, including alternative specific constants; $\bar{Z}_{j}$ designates characteristics of each respondent that are hypothesized to influence choices; and $\varepsilon_{i j}$ is assumed to be i.i.d. and follow a type I extreme value distribution. Conventional practice assumes the error reflects unobserved heterogeneity in the preferences of the respondents to these surveys from the analyst's perspective.

Before turning to the interpretation of the estimates, a few clarifications and additional details should be noted. In linear models, characteristics that do not vary across choice alternatives such as income and individual characteristics do not enter the estimating equation. In one model specification we allow for differences in responses that might arise due to the income level by allowing the coefficient on $c_{i j}$ to vary discretely with income. A second issue concerns the way that observable features of respondents are tested as potential determinants of their choices. The product $\bar{A}_{j} \cdot \bar{Z}_{i}$ is a short hand for specifications that include respondent attributes interacted with alternative specific constants for the plans. For a respondent's characteristics to be included in simple RUM models they must be interacted with attributes of the choice alternatives or with an alternative specific constant.

\section{Form of the Stated Choice Airline Security Survey}

\section{A. $\quad$ Structure of Questions}

There are four important aspects of the design of a conjoint question for estimating economic tradeoffs: (a) the presentation of the problem context and baseline conditions; (b) the description of 
the plans to address the problem and their attributes; (c) the experimental design describing both the variation in attributes across choice alternatives and the choice sets presented to each respondent; and (d) the specification of a credible choice mechanism and payment vehicle. We discuss each in turn.

The survey introduces the choice context by describing the threats to the commercial airline system from shoulder mounted missiles and emphasizing the impact on the economy for a successful attack. We characterize the potential impact on the economy (or preventing an impact on the economy) as a public good. The background discussion also assures respondents that the risks to each traveler are very small regardless of the plan. Figure 1 contains the background text. After that material the questionnaire introduces the conjoint questions by describing security plans that respond to the threat. Figure $1 \mathrm{~b}$ presents the key elements of each of three plans. The plans are: (1) an anti-missile laserjamming diversion system for heat seeking missiles that is installed on commercial aircraft; (2) equipment to prevent fuel tank fires and new training for pilots to increase the prospects for a safe landing in the event of a missile attack; and (3) new patrols around the twenty largest airports to reduce terrorist access to areas where missiles could be launched.

Each plan is described in one-half to three-quarters of a screen, along with the summary given in Figure 2 as well as the summaries provided with the choice questions. Figure 3 reproduces one of the actual choice questions. Each screen includes a choice between two of the three plans or the "no plan" status quo alternative (the opt-out alternative). In the choice questions, two other attributes also vary across plans - the proposed cost and an increase in the time a passenger can expect to spend waiting in line as part of airport screening. The three levels for the waiting time attribute are a 10, 22 and 35 minute increase in waiting time (in addition to current waiting times). Waiting time is not linked to the plans but is described as follows in the survey: "As the number of air passengers returns to normal levels, people who travel on airplanes may have to wait longer in security lines to maintain the current level of protection against the threat of hijacking." Later, before answering the questions, the 
respondents were reminded that "The amount of time passengers have to wait in line does NOT affect the level of airplane security from missile attacks; screening is necessary to protect from hijacking threats so the increased waiting time only affects the convenience of air travel for passengers." This question allows us to evaluate whether respondents who are frequent fliers noticed these distinctions as a cross check of the overall survey results. ${ }^{9}$

The cost of the plan was described in the text before the conjoint questions as a "transportation security fee". The fee was presented two different ways to randomly assigned sub-samples. Half of the respondents received a questionnaire in which the fee was described as an addition to the respondent's federal income taxes. The additional tax varied over four values-- $\$ 8, \$ 15, \$ 50$, and $\$ 120$. The other half of the sample received a gasoline tax version in which the fee was added to the cost of a gallon of gasoline. At the outset of the survey respondents were asked the number of vehicles they owned and their typical weekly gasoline expenditures. These responses were used together with a percentage increase in weekly gasoline expenditures to define the estimated cost they would experience. The percentage increase varied over four values $-1 \frac{1}{2} \%, 2 \frac{1}{2} \%, 5 \%$ and $15 \%$. As figure 3 indicates the increase in gasoline expenses is presented in three ways -- as an increase in weekly expenses, the corresponding annual increase (i.e. 52 times the weekly amount), and the percentage of reported typical expenses.

The last aspect of the conjoint survey is the experimental design. ${ }^{10}$ The experimental design for the conjoint questions sought to balance statistical information (efficiency), level balance, and orthogonality, while minimizing the cognitive burden on respondents. ${ }^{11}$ To generate the choice sets, we

\footnotetext{
${ }^{9} \mathrm{~A}$ common early criticism of SP methods was that respondents did not take them seriously. One element in the NOAA Panel's recommended attributes of contingent valuation surveys to ensure they met a burden of proof requirement was to include questions that allowed assessment of complementary behaviors or attitudes, changes in other activities that would be associated with the change implied by an individual's choice. Similarly the attitudes would also be ones consistent with the stated decision, see Arrow et al. [1993].

${ }^{10} \mathrm{Dr}$. Barbara Kanninen assisted in developing the experimental design.

${ }^{11}$ See Kanninen [2007] especially chapters 5, 6 and 7 for more details on how these decisions are made. Prior information about people's preferences over the attributes and the levels for the attributes, if available, can
} 
used the $\mathrm{L}^{\mathrm{MA}}$ method, which generates choice sets by drawing from a design matrix that has $\mathrm{M}$ times the number of columns needed for each choice set (see Louviere, Hensher and Swait [2000] p. 124-126). The method starts with an orthogonal main effects design. A main effects design allows for estimation of the main effects but no terms for interactions between the attributes. In our conjoint question with a primary focus on distinct plans as choice alternatives, we had no reason to believe that there would be interaction effects. Our plans had three attributes: (1) cost, which had four levels; (2) the plan description, which had three levels corresponding to the three plans; and (3) waiting time, which had three levels. Each choice question presented two plans and the "no plan" status quo option. As a result, our design development began with a balanced, orthogonal matrix with 144 pairs of plans. From it we deleted repeated choice sets and choice sets with overlaps. Because the focus of the valuation experiment was the laser jamming system, this plan was always included as one of the two alternative plans, so we also deleted choice sets that did not include the plan with jamming equipment for infrared missiles. Twelve remaining choice sets met criteria for orthogonality and balance. The 12 choice sets were divided into 6 blocks of two choice sets. One of the six blocks was then randomly assigned to each respondent as the survey was taken on line. The final design is given in Table 1.

\section{B. Implementation of Survey}

The air safety conjoint study was administered to the Knowledge Networks (KN) web panel. This panel was created using a national random-digit dial (RDD) frame that includes households with and without computers and/or internet access (houses without internet access are provided with an internet device). Appendix A describes the KN panel. The survey was launched to 3,059 panelists aged 18 or

enhance an experimental design. However, in this case, we had no information about which of the three airline security plans would be most preferred, so it was not possible to identify dominated choices or incorporate preferences into the conjoint design. 
older on March 11, 2006. By March 20, 2,250 panelists completed the survey with a completion rate of $74 \%$ and the survey was closed.

Table 2 summarizes the demographic characteristics of the KN panelists who were assigned to each payment vehicle. The means and standard deviations (in parentheses) are reported for a series of demographic, economic, and attitudinal variables. A few details related to these summary data should be noted. Income was elicited using household income in an interval format. The mid-point of each interval was assigned to each respondent. A Pareto tail adjustment was used to set the value for the income assigned to those in the highest, open-ended interval (see Miller [1966]). The risk tolerance measure was derived using a framework developed by Barsky et al. [1997]. Their index uses responses to a series of choices between a job with a fixed salary and another with a 50-50 chance of two different income levels, one higher than the fixed salary and one lower. With locally constant relative risk aversion, the answers classify respondents into one of four risk tolerance groups. ${ }^{12}$ We use the numerical scores assigned to each group by the risk index. The attitude measure "Importance Airline Security" equals " 1 " if the respondent selected "security from terrorism or crime" in response to the question "When you travel by commercial airline, which of the following is most important to you? Please check only one answer." and zero otherwise. ${ }^{13}$

As we noted $74 \%$ of those invited to take the survey actually completed it during the time span allowed for data collection, which raises the possibility of selection effects for those responding compared to the overall $\mathrm{KN}$ panel. $\mathrm{KN}$ provided the socio-economic characteristics of all panelists invited to take the survey so it is possible to consider selection effects as part of the choice model. A

\footnotetext{
${ }^{12}$ The formulation of the Barsky et al. [1997] question allows each respondent to be placed in intervals based on their response to an initial question and a follow up that changes the rewards up or down based on whether they accepted or rejected the initial offer. Their risk tolerance index, $\theta$, is the reciprocal of the coefficient of relative risk aversion. If $\mathrm{U}(\mathrm{y})$ is the utility function expressed in terms of annual income, $y$, then $1 / \theta=$ coefficient of relative risk aversion $=-y\left(U_{y y} / U_{y}\right)$.

${ }^{13}$ The other issues included in the question were: Cost of travel, safety from accidents, amount of time it takes to get where you want to go, level of convenience of traveling by air and the level of customer service you receive.
} 
probit selection model evaluating the attributes of $\mathrm{KN}$ respondents who completed the survey compared to those who were invited but did not take the survey indicate that older, white, and/or unemployed KN panelists were more willing to take the airline security survey. We use this model to construct an estimate of the inverse Mills ratio and test for the potential effect of selection on the KN panelist choices. ${ }^{14} \mathrm{~A}$ second selection effect arises with the decision to participate in the KN panel itself. While this selection effect is beyond the scope of our project, Appendix A discusses some of the research on the question. While the literature documents selection effects in the creation of the panel, they also found no evidence that these selection effects impact responses to questions concerning people's attitudes toward government or willingness-to-pay questions about the environment.

\section{Results}

\section{A. $\quad$ Model Estimates}

Table 3 reports the results of four choice models estimated using McFadden's [1974] logit framework. These models are replicated for each payment vehicle-the increase in the gasoline tax and the increase in income tax. While our survey was conducted in 2006, before the recent dramatic increases in the price of gasoline, we were nonetheless concerned that respondents might not accept the gas tax as a payment vehicle. However, our experience was quite different. People apparently saw the gasoline tax increase as relevant to the issue of homeland security. In focus groups conducted as part of this research, this general attitude was confirmed. The participants described the U.S. security problems as related to our dependency on foreign sources of oil.

\footnotetext{
${ }^{14}$ The probit selection model describing the attributes of the KN panelists that are associated with who accepted the invitation to participate is given as follows (the values in parentheses below the estimated parameters are the asymptotic $Z$ statistics for the null hypothesis of non-association):

Participate in airline security survey $(=1)=-.391+.048 \times 10^{-5}$ household income(measured in

$(-4.10) \quad(0.73)$

dollars $)+.068$ own home $(=1)-.064$ female $(=1)+.299$ white $(=1)-.124$ black $(=1)+.130$ college

$\begin{array}{llll}(1.16) \quad(-1.27) \quad(4.69) \quad(-1.41) & (1.83)\end{array}$

graduate $(=1)+.017$ age (years) +.286 unemployed $(=1) \quad$ pseudo $R^{2}=.0595$

(10.37) (2.48)
} 
The four models presented in Table 3 are distinguished based on: (1) the inclusion of an inverse Mills term as an approximate test for a selection effect arising from the difference between panel members who accepted the invitation to complete the survey and those who did not; (2) distinguishing the effects of different income levels on the choice of plans; and (3) accounting for observable characteristics and attitudes of respondents that are hypothesized to influence choices. Model (1) is the simplest specification including the proposed price (an increase in gasoline expenditures from the gasoline tax or an increase in the income tax), the increased waiting time for security checks, and alternative specific constants for each plan. Model (2) includes the inverse Mills ratio as a control for the panel selection effect calculated using the probit model reported in footnote 13 . The Mills ratio is interacted with the security waiting time attribute based on the hypothesis that respondents sensitive to time costs of activities might also be less willing to accept invitations to complete the internet surveys. Model (3) includes these effects and allows the effect of price to be different across income groups. ${ }^{15}$ Model (4) uses this treatment of the marginal utility of income and allows for differential effects - through the interactions described in general terms in equation (1) for our measure of risk tolerance as well as attitudes toward airline security and a qualitative variable included in models (3) and (4) for respondents who report flying frequently in the last six months.

\footnotetext{
${ }^{15}$ The definitions for each income group were: inc $1=1$ if household income is less than or equal to 27,500 ; inc $2=$ 1 if income is greater than 27,500 and less than or equal to 55,000 ; inc $3=1$ if income is between 55,000 and 112,500 ; and inc $4=1$ if income is greater than 112,500.
} 
Before comparing the estimates across payment vehicles, we should note that while we report one set of estimates, the models for the gasoline tax were estimated in two ways. First we set the cost equal to the increase in expenditures based on the respondents' reported typical weekly gasoline expenditures and the randomly assigned percentage increase in the conjoint question. Next we used an instrument to account for respondents who assume they could adjust driving behavior in response to higher gasoline prices and would not actually have to pay the full increase. The instrument regresses reported gasoline expenditures on the current gasoline taxes in the respondent's state of residence, their reported income and the number of vehicles they owned. The predictions from this model were used as the base for computing the proposed cost of each program used in the conjoint analysis. ${ }^{16}$ The estimates in Table 3 are based on the second approach using computed expenditures because it attempts to control for adjustments respondents may have made in interpreting the actual costs they would experiences (after adjusting their driving patterns in response to any increase unit charge added to the price of gasoline) .

Within a payment vehicle, the results for the choice models are quite stable with the laser jamming security system having the largest estimated alternative specific coefficient. ${ }^{17}$ All the other

\footnotetext{
${ }^{16}$ The equation below presents the estimated equations for deriving our instrument for gasoline expenditures, with $\mathrm{t}$-statistics in parentheses below the estimated parameters

$\ln ($ gas exp) $\quad=\quad 1.22-.076 \ln ($ gas tax $)$

(5.03) $\quad(-1.16)$

$+\quad .165 \ln$ (income) +.366 (no. of cars owned)

$R^{2}=.274 \quad n=2092$

The adjustment uses a variation on Goldberger [1968] adjustment for bias in the expected value of the exponentiated value of the log of gas expenditures. Our instrument is exp(predicted log of gas expenditure $.5 \hat{\sigma}^{2}$ ), where the predictions are based on the above equation and $\hat{\sigma}^{2}=$ the estimated variance of the predictions from the equation.

${ }^{17}$ With discrete choice models the estimated parameters are ratios of the effect hypothesized to be measured by the coefficient to the unobserved error's scale parameter. Both cannot be separately identified. As a result, strictly speaking we can expect the scale parameter estimate would change across model specifications within
} 
estimated parameters are consistent with what would be expected from economic choices. In Models (1) through (3), the effect of price is generally negative and statistically significant regardless of payment vehicle. Increased time for security checks has a negative and significant effect in model (1). In model (2), the interaction term between waiting time and the Mills ratio is negative and significant in the gas tax sample. Finally in model (3) time in security lines is influential to the choices of those respondents who report that they fly a lot.

Turning to the selection effect, the interaction term between time spent in security lines and the Mills ratio is negative and significant for the three gasoline tax models that include the term, but insignificant in the income tax models. In the gasoline tax model (2), the addition of the selection effect interaction term changes the sign and significance of the security time waiting coefficient (Time). Longer waiting times still reduce support for the plans, but the effect is stronger in individuals with a high Mills ratio value. Developing a hypothesis for the direction of the of the selection term is more complex than the conventional selection model where the inverse Mills ratio is reflecting the conditional expectation of the model's error given the unobserved heterogeneity for the relationship governing selection into the sample falls above an observable threshold. For this simple additive relationship we would consider the correlation between the two error terms reflecting unobserved heterogeneity to describe the expected sign of the selection effect. Positive correlation implies that those who participate would be more likely to do more of the activity being modeled. The marginal effect of an independent variable reflects the propensity of the sample to do whatever is modeled and the selection effect adjusts it so that it is relevant for the overall sample (based on the selection model as a maintained hypothesis). Thus, with a positive correlation the measured effect for an independent variable (without considering the selected nature of the sample) is larger than it should be and the selection term would adjust so it had a smaller effect for the overall sample.

each payment vehicle. We report estimates of marginal willingness to pay computed as ratios of coefficients to allow more direct comparisons that are not affected by the parameter normalization used in the RUM framework. 
The specification we used to include an ad hoc selection term in the conjoint choice framework is more complex. We can only recover an effect of selection if the inverse Mills term is interacted with plan attributes. We hypothesize that this interaction is likely to be most informative with the term for the increased time in security. Our reasoning for describing its affect on the choice model is as follows. Respondents in our sample would be less sensitive, all else equal, to requests for their time. They completed the invitation sent to the KN panelists sooner than other panelists. Thus, in a choice context the estimates for the effects of increased time would be smaller in absolute magnitude than they would be if the full sample included more time sensitive respondents. Using the selection term to compute the overall effect of increased waiting time on a choice should be negative so this positive correlation would support a negative coefficient for the interaction term between the inverse Mills term and the increased time for security. Of course, we should add that it could well be that KN survey respondents view the time spent answering surveys and the time spent in security lines at airports very differently. In this case we could not offer a specific hypothesis for the sign of the coefficient's effect on choices involving increased time in security lines. The standard errors are based on STATA's robust estimator for the case of maximum likelihood estimation to allow for the heteroscedasticity associated with estimating the Mills term.

Turning to model (4), price is interacted with the qualitative variable identifying income groups and the Barsky et al. measure of risk tolerance (RTOL). Generally the results are not significant, except for the lowest income group for the income tax payment vehicle. It is difficult to know how to interpret this result because the risk tolerance measure does not appear to influence the choice of plans. When we compare the estimates of the coefficient of risk aversion by income group and payment vehicle, the second income class $(\$ 27,500-\$ 55,000)$ and the highest income group have the largest average value for the risk tolerance. For the sample receiving the gas tax payment vehicle these means are approximately comparable. The sample with the income tax payment vehicle had quite different means for the risk 
tolerance measure with the highest income group having an appreciable higher risk tolerance $(0.494$, with the range from 0.11 to 1.61 ) than the second income group (0.430). It is not possible to assess whether these differences in average risk tolerance across groups contribute to the estimated role for interactions of risk tolerance with the effects of price and level of income on choices. We only find a significant difference for low income households, who would be judged more tolerant of financial risks based on this question.

Respondents with concerns about security are willing to pay more for any of the plans for both payment vehicles. The survey apparently did a good job convincing respondents to the gas tax version that the plans would not affect a specific traveler's risk of being involved in a missile attack on a commercial aircraft, as reflected by the insignificant interaction effect of the qualitative variable used as a proxy measure to identify frequent fliers with the alternative specific constants for the plans for the gasoline tax version. In the income tax version, the interaction term is negative for all three plans and significant for all but the plan proposing increased patrols in the largest airports. Considering model (3) for both payment vehicles, frequent fliers were sensitive to security waiting times, so these respondents appear to have distinguished the features of the choice alternatives.

Comparing the results across payment vehicle-there are direct differences in the estimated coefficients for the prices and alternative specific constants for all models. The normalization restrictions on the estimated parameters make this effect difficult to interpret using the parameters alone. As a result, we considered the estimate for the marginal willingness to pay (MWTP) for each plan based on the simple models and turn to these results below.

Table 4 reports estimates for MWTP for each payment vehicle, model, and plan. Considering first the gasoline tax models, the plan to install laser jamming devices generates the largest MWTP. It is remarkably stable across specifications and, as noted, varies as we would expect with income level of the respondent when the model is altered to allow a different marginal utility of income for each of four 
income classes. ${ }^{18}$ In contrast, MWTP for the plan to introduce patrols was not significantly different from zero for the sample receiving the gasoline tax as the payment vehicle. Across both payment vehicles (gasoline tax versus income tax), taking account of selection does not influence the ranking of the security plans within a payment vehicle (comparing model (1) and model (2)).

The respondents to the income tax payment vehicle questions have the same ranking of the three plans based on MWTP, but there are large differences in the estimated magnitudes of the MWTP for each plan from those estimated using the gasoline tax sample. The MWTP estimates for the laser jamming and fuel tank protection plans are lower with the income tax payment vehicle compared to the gasoline tax plan. Using the asymptotic standard errors, these differences would be judged significantly different for the laser jamming plan with models that do not distinguish separate income effects (Models (1) and (2)). ${ }^{19}$ Otherwise, the estimated MWTP were not significantly different across the two payment specifications. Using income tax payment vehicle, respondents' choices implied equal MWTP for the plan to strengthen the fuel tank and train pilots and the plan to patrol around the largest airports.

After the conjoint questions, the survey included questions about the respondents' opinions about the three plans, the plans' cost, and other topics related to the responses to the conjoint questions. There is an interesting distinction in the perceptions of the likely success of the patrolling plan between respondents who live in states with at least one of the twenty largest airports and those who do not. Respondents in a state without one of the twenty largest airports and do not fly a lot are significantly more likely to believe that the patrolling plan is not likely to work than those who are also infrequent fliers but live in a state with one of these airports. There are some small differences in the

\footnotetext{
${ }^{18}$ We also grouped respondents by estimates of their marginal tax rates as well as into two income groups-low and high income and the results are comparable, suggesting the general conclusion that the willingness to pay estimates for plans increase with income is not the result of the specific definitions selected for these four income classes.

${ }^{19}$ The asymptotic $Z$ statistic for testing the null hypothesis of equality is 2.6 .
} 
assignment of the gasoline and income tax versions of the surveys to states with large airports, but a cross tabulation of the distributions did not indicate a significant difference in these assignments. However, these apparent differences in attitudes might be argued as partially explaining the difference in the economic valuation of plans across the two samples. Regardless at best this difference in attitudes would account for a small portion of the differences in the estimates for the two payment vehicles.

Thus, it would seem the difference in MWTP is difficult to explain based on the economic characteristics and attitudes of the two samples alone. Instead we believe that the differences arise primarily from differences in the attribute levels for cost in the two samples. The gas tax payment vehicle does a better job at presenting respondents with costs that are closer to their "choke" prices. Table 5, reports the distribution and summary statistics for the prices actually assigned to each respondent by payment vehicle and plan. The highest cost under the income tax payment vehicle $(\$ 120)$ is far below the highest cost presented in the gas tax version. The design values for the percentage increase in the gasoline tax we selected for the conjoint questions were based on average expenditures for typical households. We selected the design values with the ex ante expectation that the costs under the two payment vehicles would be approximately comparable once the respondents' reported weekly gasoline expenditures were factored in. As Table 5 indicates, the actual median cost increase in gasoline expenditures presented in the survey for the plan to use jamming devices closely matches the median increase in income tax for this plan. Since all respondents received this plan in both samples, this assignment matches our design criteria reasonably well. ${ }^{20}$ However, the medians for the other plans are not as similar. Moreover, the ranges of actual costs for the three plans for the gasoline tax version of the survey are much larger than with the income tax. For this reason we believe the gasoline tax version is pushing some respondents closer to their choke prices, resulting in higher MWTP estimates. This conclusion also stems from the use of a linear choice model -where the marginal effect

\footnotetext{
${ }^{20}$ Every respondent in both samples received the laser jamming plan so the first column in Table 5 summarizes the results for the full sample.
} 
of the annual cost is assumed to be approximately constant over the range of costs proposed in each sample. The highest estimates for the MWTP for the laser jamming plan under the income tax version are for the two highest income classes and could well have been substantially higher-if the design had allowed consideration of larger costs. Thus, we hypothesize that this difference in assigned costs for plans explains most of the difference in MWTP estimates across the two payment vehicles.

Unfortunately we do not have sufficient variation in the design points for plan costs with the income tax version of the payment to test this hypothesis.

Overall, the results for both payment vehicles present a consistent description of respondent preferences with clear support for the laser jamming system over the other two alternatives, consistent responsiveness to attributes and attitudes across the payment vehicles and consistent variation in MWTP responsiveness to income. This pattern is especially apparent with the gasoline tax.

\section{Plausibility Cross-Checks for the Stated Choices}

In this section we present some additional results to help gauge the plausibility of the SP MWTP estimates. Consistent links between observable features or attitudes of respondents to their choices is an indication of plausibility. As discussed in the previous section, the responses were sensitive to the cost of the plan and the income of the respondents. In addition, the difference in the significance of the security waiting time coefficient across frequent and infrequent fliers indicates respondents recognized the relevance of the design attributes to their situation. In all these cases, our survey responses are consistent with what one would expect from economically meaningful choices.

As mentioned in the previous section, the survey included a set of questions about the plans, payment vehicles, and other attitudes that might be correlated with an individual's response to the conjoint questions. Table 6 provides three gauges. The first panel is a split comparing the respondents who describe the reason they voted for no plan as being due to "high taxes" (or price of gasoline was 
too high). Those receiving the gasoline tax were more likely to cite this reason than those receiving the income tax. This finding is consistent with our discussion of the implications of the range of costs assigned under this payment scheme for estimates of the marginal willingness to pay. When respondents receive proposed costs that span a range more likely to capture all respondents' choke prices for the programs then we should expect a different rate at which respondents identify costs as their reason for not selecting a plan. The second panel gauges the consistency between the statements of concern about terrorists' use of missiles and the decisions to support the plan. For both of the payment vehicles, we see the expected pattern. Those who are very concerned or somewhat concerned are more willing to select a plan. Finally the last panel examines whether responses that the laser jamming plan is not likely to work were different between the two payment schemes. At the ten percent level we would conclude there was a difference. Ideally one would not want responses on the plans effectiveness to differ with payment vehicle. The explanations in other dimensions are completely comparable. However the higher costs may have caused some respondents to consider the plan's effectiveness more carefully than they would have if the costs were lower.

\section{Summary and Implications}

Over the past seven years since $9 / 11$ federal expenditures for homeland security have increased substantially. ${ }^{21}$ These actions are consistent with reported public concerns about terrorist threats. The majority of the economic research on security has focused on indirect measures of the effects of terrorist threats for the level of economic activity, the structure of urban property markets, and precautionary behaviors people are willing to undertake. None of these studies consider observed behaviors with sufficient resolution in choices to estimate the implied tradeoffs people are making to enhance their security.

\footnotetext{
${ }^{21}$ Sandler et al (2007) report estimates for 2005 that are approximately $\$ 30$ billion dollars.
} 
This research exploits the advances in SP methods to estimate the tradeoffs implied by people's choices of different security plans. Our survey suggests it is possible to estimate the economic tradeoffs people would be prepared to make to reduce the prospects for threats of disruption to the commercial aircraft sector and the resulting impacts on the U.S. economy. The formulation of the question emphasized the aggregate economic losses and thus the public dimensions of the protection provided by specific plans.

Estimates of household MWTP for the laser jamming system (using a conservative summary of the estimates across payment vehicles) range from $\$ 100$ to $\$ 220$ annual per household. Von Winterfeldt and O'Sullivan's [2006] decision theoretic analysis of the laser jamming plan suggests that the countermeasures would be preferred if economic losses are above $\$ 74$ billion, the probability of attack is larger than 0.37 in ten years and if the cost of the measures is less than about $\$ 14$ billion. Our MWTP estimates suggest that even using the most conservative of our estimates a program with a cost consistent with their thresholds would yield significant net benefits.

This type of analysis seems likely to be increasingly important to the design and implementation of homeland security policies. A recent Office of Management and Budget (OMB) evaluation of the regulatory impact analysis (RIA) for major rules indicated that DHS has faced less stringent review of their benefit assessments than other Federal agencies (OMB 2007). To date there has been very little experience with measuring the benefits of security policies. For the most part, DHS assessments have relied on the fatality consequences of successful attacks and assumed the benefits are associated with each policy's estimated risk reduction or they have relied on upper bound measures. This later group compares the event being influenced by the policy to $9 / 11$ and implicitly asks the rhetorical question of its impact compared to the attack on the World Trade Center and the Pentagon. Most of the DHS RIA's describe the benefits of a policy qualitatively, rather than quantitatively (see OMB 2008 or OMB 2007 
for examples). One reviewer of the OMB summary document implied that the "free ride" that DHS benefit-cost evaluations enjoyed at OMB would not persist indefinitely (OMB 2007).

The results reported in this paper suggest that people can make choices over security choices when they are described using specific plans. The results also indicate that the tradeoffs their choices imply are economically consistent. While some might argue that specific security policies are too complicated for the public to understand, public opinion plays an important role in Congressional support for different policies. Public opinion about government policies also affects the degree to which individuals change their own behavior, and thus the costs and benefits of the policy. The range of MWTP estimates indicates that the heterogeneity in these measures for the tradeoffs respondents would make is consistent with their circumstances and opinions about the nature of terrorist threats. The estimated MWTP also seems reasonable compared to the costs of a successful attack and relative to other insurance payments such as automobile and home insurance.

Nonetheless it is unlikely that policy staff will have the resources or time to prepare a new stated choice survey (or identify revealed preference behaviors) to estimate benefits for each new policy. The time available for analysis is limited and often the assessment methods must be flexible so they can adapt to the changing status of rules as they are designed. Thus, the real challenge facing benefit-cost analysis of homeland security policies is the development of a set of tradeoff studies that will permit the type of benefit transfer strategies commonly used in assessments of rules associated with environmental policies. 


\section{REFERENCES}

Abadie, Alberto and Javier Gardeazabal, 2003, "The Economic Costs of Conflict: A Case Study of the Basque Country," American Economic Review, Vol. 93 (March): 113-132.

Abadie, Alberto and Sofia Dermisi, 2006, "Is Terrorism Eroding Agglomeration Economies in Central Business Districts? Lessons from the Office Real Estate Market in Downtown Chicago", NBER Working Paper No. 12678, November, Journal of Urban Economics, forthcoming

Arrow, Kenneth J., Robert Solow, Paul R. Portney, Edward E. Leamer, Roy Radner, and Howard Schuman, 1993, 'Report of NOAA Panel on Contingent Valuation” Federal register 58, 4601-4614.

Balvanyos, T. and Lester Lave, 2005, "The Economic Implications of Terrorist Attack on Commercial Aviation in the USA," report to the Center for Risk and Economic Analysis of Terrorism (CREATE), University of Southern California, Los Angeles.

Banzhaf H.Spencer, Dallas Burtraw, David Evans, and Alan Krupnick. 2004. "Valuation of Natural Resource Improvements in the Adirondacks" Resources for the Future working paper.

Barsky, Robert B., F. Thomas Juster, Miles S. Kimball, and Matthew D. Shapiro, 1997, "Preference Parameters and Behavioral Heterogeneity: An Experimental Approach in the Health and Retirement Study," Quarterly Journal of Economics, Vol. 112 (May): 537-580.

Becker, Gary S. and Yona Rubinstein, 2004, "Fear and the Response to Terrorism: An Economic Analysis," unpublished paper, Department of Economics, University of Chicago, August 1.

Berrens, Robert P., Alok K. Bohara, Hank Jenkins-Smith, Carol Silva, and David L. Weimer, 2003, “The Advent of Internet Surveys for Political research: A comparison of Telephone and Internet Samples," Political Analysis, Vol. 11 (1): 1-22.

Cameron Trudy A. and J.R. DeShazo, 2004. "Valuing Health-Risk Reductions: Sick-years, Lost Life-Years, and Latency" http://faculty.spa.ucla.edu/deshazo/pdf/13/general paper .pdf 
Cameron, Trudy A. and J.R. DeShazo, 2005, “Comprehensive Selectivity Assessment for a Major Consumer Panel: Attitudes Toward Government Regulation of Environment, Health, and Safety Risks," unpublished paper, Department of Economics, University of Oregon, November.

Carson, Richard T. and W. Michael Hanemann, 2005, "Contingent Valuation" in Karl Göran-Mäler and Jeffrey R. Vincent editors, Handbook of Environmental Economics, Vol. II (Amsterdam: North Holland), pp. 821-936.

Carson, Richard T., Robert Cameron Mitchell, W. Michael Hanemann, Raymond J. Kopp, Stanley Presser, and Paul A. Ruud, 2003, “Contingent Valuation and Lost Passive Use: Damages from the Exxon Valdez Oil Spill”, Environmental and Resource Economics, Vol. 25 ( July):257-286.

Dennis J.M., C. Chatt, R. Li, A. Motta-Stanko and P. Pulliam. 2005. "Data Collection Mode Effects Controlling for Sample Origins in a Panel Survey: Telephone versus Internet"

Diamond, Peter A. and Jerry A. Hausman, 1994, "Contingent Valuation: Is Some Number Better than No Number?," Journal of Economic Perspectives, Vol. 8 (Fall): 45-64.

Eckstein, Otto, 1961, Water Resource Development: The Economics of Project Evaluation, (Cambridge, Mass.: Harvard University Press).

Frey, Bruno S., Simon Luechinger and Alois Stutzer, 2007, “Calculating Tragedy: Assessing the Costs of Terrorism," Journal of Economic Surveys Vol. 21, (1): 1-24.

Glaeser, E.L., J.M. Shapiro, 2002, “Cities and Warfare: The Impact of Terrorism on Urban Form,” Journal of Urban Economics, 51(2): 205-224.

Goldberger, Arthur S. 1968, "The Interpretation and Estimation of Cobb Douglas Functions," Econometrica, Vol. 35 (April): 464-472.

Gordon, Peter, James E. Moore II, Ji Young Park, and Harry Richardson, 207, "The Economic Impacts of a Terrorist Attack on the U.S. Commercial Aviation System," Risk Analysis, Vol. 27 (3): 505-512. Hall, Mimi, 2008, “Passenger Jets Get Anti-Missile Devices," U.S.A. Today. January 4-6. 
Hensher David A.,John M. Rose, and William H. Greene, 2005, Applied Choice Analysis: A Primer (Cambridge: Cambridge University Press)

Johnson, F. Reed, Barbara J. Kanninen, Matthew Bingham, Semra Özdemir, 2007, “Experimental Design for Stated Choice Studies," B.J. Kanninen editor, Valuing Environmental Amenities Using Stated Choice Studies, (Dordrecht, The Netherlands: Springer) pp 297-333.

Kanninen, Barbara J., editor, 2007, Valuing Environmental Amenities Using Stated Choice Studies, (Dordrecht, The Netherlands: Springer).

Krosnick, J.A. and L.C. Chang, 2001. "A Comparison of the Random Digit Dialing Telephone Survey Methodology with Internet Survey Methodology as Implemented by Knowledge Networks and Harris Interactive." Ohio State University, http://www.knowledgenetworks.com/ganp/reviewerinfo.html.

Landry, Craig E. and John A. List, 2007, “Using Ex Ante Approaches to Obtain Credible Signals for Value in Contingent Markets: Evidence from the Field," American Journal of Agricultural Economics, Vol. 89 (May): 420-429.

Louviere, Jordan J. 1988, Analyzing Decision Making: Metric Conjoint Analysis, Sage University Paper Series on Social Sciences 07-67, Sage Publications, Newbury Park, CA.

Louviere, Jordan J., David A. Hensher, and Joffre D. Swait. 2000, Stated Choice Methods: Analysis and Applications. (New York: Cambridge University Press).

McFadden, Daniel, 1974, "Conditional Logit Analysis of Qualitative Choice Behavior," in P. Zarembka editor, Frontiers of Econometrics (New York: Academic Press), pp. 105-142.

Miller, Herman P. 1966, Income Distribution in the United States, (A 1960 census monograph). Washington, D.C.: U.S. Government Printing Office.

Office of Management and Budget, 2008, 2007 Report to Congress on the Costs and Benefits of Federal

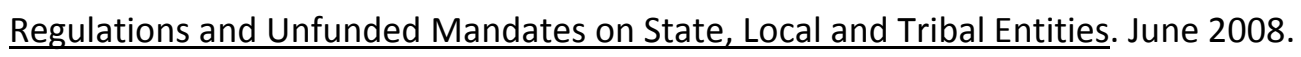


Office of Management and Budget, 2007, 2006 Report to Congress on the Costs and Benefits of Federal Regulations and Unfunded Mandates on State, Local and Tribal Entities. January 2007.

Samuelson, Paul A., 1976, Economics, $10^{\text {th }}$ Edition (New York: McGraw Hill).

Sandler, Todd,, Daniel Arcie, and Walter Enders, 2007, "Transnational Terrorism" In Bjorn Lomberg (ed), Global Crisis, Global Solutions, Copenhagen Consensus 2008 (Cambridge: Cambridge University Press, 2009) forthcoming.

Santos, J.R. and Y.Y. Haimes, 2004, "Modeling the Demand Reduction Input Output Inoperability due to Terrorism of Interconnected Infrastructures," Risk Analysis, Vol. 24(6): 1437-1451.

Smith, V. Kerry,1997, "Pricing What is Priceless: A Status report on Non_market Valuation of Environmental Resources" in Henk Folmer and Tom Tietenberg, editors, The International Yearbook of Environmental and Resource Economics (Cheltenham, U.K: Edward Elgar) pp.156204.

Smith, V. Kerry, 1996, "Resource Evaluation at the Crossroads" address for thirty-fifth anniversary of Resources for the Future, reprinted in V. Kerry Smith, editor, Estimating Economic Values for Nature (Cheltenham,U.K.: Edward Elgar) pp 2-41.

Smith, V. Kerry. 2007, “Judging Quality," B.J. Kanninen editor, Valuing Environmental Amenities Using Stated Choice Studies, (Dordrecht, The Netherlands: Springer) pp 297-333.

Viscusi, W.Kip, Joel Huber, and Jason Bell. 2004 "The Value Of Regional Water Quality Improvements", The Harvard John M. Olin Discussion Paper Series Discussion Paper No. 477, http://www.law.harvard.edu/programs/olin_center/

Viscusi, W. Kip and Richard J. Zeckhauser, 2003, "Sacrificing Civil Liberties to Reduce Terrorism Risk," Journal of Risk and Uncertainty, Vol. 26 (March/May): 99-120.

von Winterfeldt and Terrence M. O’Sullivan, 2006, “Should We Protect Commercial Airplanes Against Surface-to-Air Missile Attacks by Terrorists?" Decision Analysis, Vol. 3, (June): 63-75. 
Zussman, A., N. Zussman, and M. Nielson, 2008, "Asset Market Perspectives on the Israeli-Palestinian Conflict," Economica, 75(297): 84-115.

Zwerina, K, Joel Huber, and W. Kuhfeld, 1996, "A General Method for Constructing Efficient Choice Designs." Durham: Fuqua School of Business, Duke University. 


\section{Figure 1: Threat form Missile Attacks on Airlines}

\section{Airline Security}

The terrorist hijacking of commercial airplanes and attacks on the World Trade Center and the Pentagon on September 11, 2001, led to major changes in airport security screening. Despite the increase in airport security, there are a number of continuing threats to air travel safety.

The Department of Homeland Security has identified ground-to-air missiles as an important threat to the security of the air transportation system in addition to the on-going threats posed by hijacking.

Ground Attacks with Missiles: Commercial aircraft can be attacked from the ground with small surface-to-air missiles (SAMs). These missiles can be carried by a single person and are fired from an area close to the airport.

The three main kinds of surface-to-air missiles are:

- Heat-seeking: target heat sources on an aircraft;

- Laser-guided: follow a laser path aimed at the aircraft and require extensive training and skill;

- Command line-of-sight missiles: directed using radio controls and require a very high level of skill;

It is estimated that there are at least 4,000 to 5,000 missiles that may be accessible to anti-Western terrorists. The majority of these missiles are heat seeking.

The chances that you would actually be on a plane experiencing a missile attack or a hijacking is very, very small, even if you fly a great deal.

In U.S. airports, over 75,000 commercial airplanes depart on an average day, ranging from over 100 departures to over 1,100 departures a day at the 50 largest U.S. airports.

An important reason for government concern is the security and reliability of the commercial air transportation system.

\section{One successful attack would affect everyone in the U.S.}

When people are killed in an attack it increases feelings of insecurity and reduces people's willingness to travel by air. The airline industry still suffers from the drop in air travel after 9/11. A 10\% decline in airline travel reduces economic activity by about $\$ 40$ billion a year. Another successful hijacking or missile attack would have serious impacts on our transportation system and on the whole U.S. economy. 
Figure 2: Description of Missile Defense Systems

\begin{tabular}{|c|c|c|}
\hline Detect \& Divert & $\begin{array}{c}\text { Preventing Fires \& Landing } \\
\text { Safely }\end{array}$ & Patrolling Around Airports \\
\hline $\begin{array}{l}\text { - All U.S. airplanes install system } \\
\text { to detect and divert heat- } \\
\text { seeking missiles. } \\
\text { - Very effective as soon as it is } \\
\text { installed. } \\
\text { - Only works for heat-seeking } \\
\text { missiles. } \\
\text { - Heat-seeking missiles most } \\
\text { common. }\end{array}$ & $\begin{array}{l}\text { - All U.S. airplanes install fuel tank } \\
\text { fire suppression systems } \\
\text { - Additional pilot training to safely } \\
\text { land missile-damaged plane } \\
\text { - Moderately effective with } \\
\text { sufficient time to develop } \\
\text { systems and training } \\
\text { - Works for all types of missiles }\end{array}$ & $\begin{array}{l}\text { - Guards would patrol the area } \\
\text { around } 20 \text { largest airports } \\
\text { - Moderately effective } \\
\text { - Works for all types of missiles } \\
\text { as well as other threats to } \\
\text { airports }\end{array}$ \\
\hline
\end{tabular}


Figure 3: Sample Choice Question

\begin{tabular}{|c|c|c|c|}
\hline & $\begin{array}{l}\text { Defense Against } \\
\text { Missiles - Detect } \\
\text { and Divert: }\end{array}$ & $\begin{array}{c}\text { Defense Against Missiles } \\
\text { - Preventing Fires and } \\
\text { Landing Safely: }\end{array}$ & Current System \\
\hline Security System & $\begin{array}{l}\text { - All U.S. airplanes install } \\
\text { system to detect and } \\
\text { divert heat-seeking } \\
\text { missiles } \\
\text { - Very effective as soon } \\
\text { as it is installed } \\
\text { - Only works for heat- } \\
\text { seeking missiles } \\
\text { - Heat-seeking missiles } \\
\text { most common }\end{array}$ & $\begin{array}{l}\text { - All U.S. airplanes install } \\
\text { fuel tank fire suppression } \\
\text { systems } \\
\text { - Additional pilot training } \\
\text { to safely and missile- } \\
\text { damaged plane } \\
\text { - Moderately effective with } \\
\text { sufficient time to develop } \\
\text { systems and training } \\
\text { - Works for all types of } \\
\text { missiles }\end{array}$ & $\begin{array}{l}\text { - No special protection } \\
\text { against surface-to-air } \\
\text { missiles }\end{array}$ \\
\hline $\begin{array}{c}\text { Increase in waiting time for } \\
\text { passengers in airport } \\
\text { security line }\end{array}$ & $\begin{array}{l}\text { Average of } 10 \text { minutes } \\
\text { more on every flight } \\
\text { you take }\end{array}$ & $\begin{array}{l}\text { Average of } 22 \text { minutes } \\
\text { more on every flight you } \\
\text { take }\end{array}$ & $\begin{array}{l}\text { - No change in waiting } \\
\text { time }\end{array}$ \\
\hline Cost to YOU & $\begin{array}{l}\text { YOUR household's } \\
\text { weekly gas expenses } \\
\text { would increase } 20 c \text { a } \\
\text { week or } \$ 10.4 \text { per year } \\
\text { (a } 1 / 2 \% \text { increase) }\end{array}$ & $\begin{array}{l}\text { - YOUR household's weekly } \\
\text { gas expenses would } \\
\text { increase } \$ 1.00 \text { a week or } \\
\$ 52 \text { per year (a } 2.5 \% \\
\text { increase) }\end{array}$ & $\begin{array}{l}\text { - No change in cost of } \\
\text { gas }\end{array}$ \\
\hline $\begin{array}{l}\text { Please select the plan you } \\
\text { would vote for; the plan } \\
\text { selected by the majority will } \\
\text { be one recommended, } \\
\text { check only one option }\end{array}$ & & & \\
\hline
\end{tabular}


Table 1: Experimental Design for the Airline Security Conjoint Survey ${ }^{a}$

\begin{tabular}{|c|c|c|c|}
\hline Version & Question & Alternative 1 & Alternative 2 \\
\hline \multirow[t]{2}{*}{1} & 1 & $\begin{array}{c}\text { Detection and Jamming Device } \\
\text { Time }=10 \mathrm{~min} . \\
\text { Cost }=\$ 8,1 / 2 \%\end{array}$ & $\begin{array}{l}\text { Training pilots } \\
\text { Time }=22 \mathrm{~min} \\
\text { Cost }=\$ 15,2.5 \%\end{array}$ \\
\hline & 2 & $\begin{array}{c}\text { Detection and Jamming Device } \\
\text { Time }=22 \min \\
\text { Cost }=\$ 8,1 / 2 \%\end{array}$ & $\begin{array}{c}\text { Patrol } \\
\text { Time }=10 \mathrm{~min} \\
\text { Cost }=\$ 50,5 \%\end{array}$ \\
\hline \multirow[t]{2}{*}{2} & 1 & $\begin{array}{c}\text { Detection and Jamming Device } \\
\text { Time }=10 \mathrm{~min} \\
\text { Cost }=\$ 15,2.5 \%\end{array}$ & $\begin{array}{l}\text { Training pilots } \\
\text { Time }=35 \mathrm{~min} \\
\text { Cost }=\$ 50,5 \%\end{array}$ \\
\hline & 2 & $\begin{array}{c}\text { Detection and Jamming Device } \\
\text { Time }=22 \min \\
\text { Cost }=\$ 15,2.5 \%\end{array}$ & $\begin{array}{c}\text { Patrol } \\
\text { Time }=35 \min \\
\text { Cost }=\$ 120,15 \%\end{array}$ \\
\hline \multirow[t]{2}{*}{3} & 1 & $\begin{array}{c}\text { Detection and Jamming Device } \\
\text { Time }=35 \min \\
\text { Cost }=\$ 8,1 / 2 \%\end{array}$ & $\begin{array}{c}\text { Training Pilots } \\
\text { Time }=10 \mathrm{~min} \\
\text { Cost }=\$ 120,15 \%\end{array}$ \\
\hline & 2 & $\begin{array}{c}\text { Detection and Jamming Device } \\
\text { Time }=22 \min \\
\text { Cost }=\$ 120,15 \%\end{array}$ & $\begin{array}{l}\text { Training Pilots } \\
\text { Time }=35 \mathrm{~min} \\
\text { Cost }=\$ 15,2.5 \%\end{array}$ \\
\hline \multirow[t]{2}{*}{4} & 1 & $\begin{array}{c}\text { Detection and Jamming Device } \\
\text { Time }=10 \mathrm{~min} \\
\text { Cost }=\$ 50,5 \%\end{array}$ & $\begin{array}{c}\text { Patrol } \\
\text { Time }=22 \mathrm{~min} \\
\text { Cost }=\$ 120,15 \% \\
\end{array}$ \\
\hline & 2 & $\begin{array}{c}\text { Detection and Jamming Device } \\
\text { Time }=35 \mathrm{~min} \\
\text { Cost }=\$ 15,2.5 \%\end{array}$ & $\begin{array}{l}\text { Training Pilots } \\
\text { Time }=22 \mathrm{~min} \\
\text { Cost }=\$ 8,1 / 2 \%\end{array}$ \\
\hline \multirow[t]{2}{*}{5} & 1 & $\begin{array}{c}\text { Detection and Jamming Device } \\
\text { Time }=10 \min \\
\text { Cost }=\$ 120,15 \%\end{array}$ & $\begin{array}{c}\text { Patrol } \\
\text { Time }=35 \mathrm{~min} \\
\text { Cost }=\$ 8,1 / 2 \%\end{array}$ \\
\hline & 2 & $\begin{array}{c}\text { Detection and Jamming Device } \\
\text { Time }=35 \mathrm{~min} \\
\text { Cost }=\$ 50,5 \%\end{array}$ & $\begin{array}{c}\text { Patrol } \\
\text { Time }=10 \mathrm{~min} \\
\text { Cost }=\$ 15,2.5 \% \\
\end{array}$ \\
\hline \multirow[t]{2}{*}{6} & 1 & $\begin{array}{l}\text { Detection and Jamming Device } \\
\text { Time }=22 \min \\
\text { Cost }=\$ 50,5 \%\end{array}$ & $\begin{array}{l}\text { Training Pilots } \\
\text { Time }=10 \mathrm{~min} \\
\text { Cost }=\$ 8,1 / 2 \%\end{array}$ \\
\hline & 2 & $\begin{array}{c}\text { Detection and Jamming Device } \\
\text { Time }=35 \min \\
\text { Cost }=\$ 120,15 \%\end{array}$ & $\begin{array}{c}\text { Patrol } \\
\text { Time }=22 \mathrm{~min} \\
\text { Cost }=\$ 50,5 \%\end{array}$ \\
\hline
\end{tabular}

${ }^{a}$ In the designation of the cost attribute the first number corresponds to the increase in the income tax and the second number to the percentage increase in gasoline expenditures. 
Table 2: Variable Names, Definitions, Means and (Standard Deviations) of the Two Samples

\begin{tabular}{|c|c|c|c|}
\hline $\begin{array}{c}\text { Variable } \\
\text { (Variable Abbreviation }^{1} \text { ) }\end{array}$ & Variable Definition $^{1}$ & $\begin{array}{l}\text { Gas Tax } \\
\text { Version }\end{array}$ & $\begin{array}{l}\text { Income Tax } \\
\text { Version }\end{array}$ \\
\hline Age & & $\begin{array}{c}47.4 \\
(16.8)\end{array}$ & $\begin{array}{c}48.7 \\
(17.0)\end{array}$ \\
\hline Proportion Female & & $\begin{array}{c}0.53 \\
(0.50)\end{array}$ & $\begin{array}{c}0.50 \\
(0.50)\end{array}$ \\
\hline Proportion White & & $\begin{array}{c}0.74 \\
(0.44)\end{array}$ & $\begin{array}{c}0.74 \\
(0.44)\end{array}$ \\
\hline Proportion Own Home & & $\begin{array}{c}0.71 \\
(0.45)\end{array}$ & $\begin{array}{c}0.69 \\
(0.46)\end{array}$ \\
\hline Proportion Retired & & $\begin{array}{c}0.16 \\
(0.37)\end{array}$ & $\begin{array}{c}0.19 \\
(0.39)\end{array}$ \\
\hline $\begin{array}{c}\text { Proportion } \\
\text { High School Grad }\end{array}$ & & $\begin{array}{l}0.31 \\
(0.46)\end{array}$ & $\begin{array}{l}0.30 \\
(0.46)\end{array}$ \\
\hline $\begin{array}{l}\text { Proportion } \\
\text { College Grad }\end{array}$ & & $\begin{array}{c}0.18 \\
(0.38)\end{array}$ & $\begin{array}{c}0.17 \\
(0.37)\end{array}$ \\
\hline Household Income & & $\begin{array}{c}53,992 \\
(40,880)\end{array}$ & $\begin{array}{c}51,665 \\
(41,459)\end{array}$ \\
\hline $\begin{array}{l}\text { Proportion of respondents in } \\
\text { income category } 1 \\
\text { (INC1) }\end{array}$ & $\begin{array}{c}=1 \text { if household income is less than or } \\
\text { equal to } \$ 27,500\end{array}$ & $\begin{array}{l}.297 \\
(457)\end{array}$ & $\begin{array}{l}.334 \\
(.471)\end{array}$ \\
\hline $\begin{array}{l}\text { Proportion of respondents in } \\
\text { income category } 2 \\
\text { (INC2) }\end{array}$ & $\begin{array}{c}=1 \text { if household income is greater than } \\
\$ 27,500 \text { and less than or equal to } \\
\$ 55,000\end{array}$ & $\begin{array}{l}.376 \\
(.485)\end{array}$ & $\begin{array}{l}.354 \\
(.479)\end{array}$ \\
\hline $\begin{array}{l}\text { Proportion of respondents in } \\
\text { income category } 3 \\
\text { (INC3) }\end{array}$ & $\begin{array}{c}=1 \text { if household income is greater than } \\
\$ 55,000 \text { and less than or equal to } \\
\$ 112,500\end{array}$ & $\begin{array}{l}.271 \\
(.445)\end{array}$ & $\begin{array}{l}.261 \\
(.439)\end{array}$ \\
\hline $\begin{array}{c}\text { Proportion of respondents in } \\
\text { income category } 4 \\
\text { (INC4) }\end{array}$ & $\begin{array}{l}=1 \text { if household income is greater than } \\
\qquad \$ 112,500\end{array}$ & $\begin{array}{l}.055 \\
(.228)\end{array}$ & $\begin{array}{l}.050 \\
(.218)\end{array}$ \\
\hline $\begin{array}{c}\text { Proportion Fly-Past } \\
6 \text { Months } \\
\text { (Flyalot) }\end{array}$ & $\begin{array}{l}\text { Proportion of respondents who have } \\
\text { flown at least once in the last } 6 \text { months }\end{array}$ & $\begin{array}{l}0.23 \\
(0.42)\end{array}$ & $\begin{array}{l}0.23 \\
(0.42)\end{array}$ \\
\hline $\begin{array}{l}\text { Risk Tolerance } \\
\text { (RTOL) }\end{array}$ & $\begin{array}{c}\text { Risk tolerance measure from Barsky et } \\
\text { al. (1997) }\end{array}$ & $\begin{array}{l}0.45 \\
(0.53) \\
\end{array}$ & $\begin{array}{l}0.43 \\
(0.52) \\
\end{array}$ \\
\hline Weekly Gasoline Expenditures & Reported weekly gasoline expenditures & $\begin{array}{c}44.58 \\
(35.79)\end{array}$ & $\begin{array}{c}43.53 \\
(33.53)\end{array}$ \\
\hline $\begin{array}{l}\text { Importance Airline } \\
\text { Security } \\
\text { (Security) }\end{array}$ & $\begin{array}{l}\text { Equals "1" if the respondent selected } \\
\text { "security from terrorism or crime" in } \\
\text { response to the question "When you } \\
\text { travel by commercial airline, which of } \\
\text { the following is most important to you? } \\
\text { Please check only one answer." and zero } \\
\text { otherwise. }\end{array}$ & $(0.30)$ & $(0.31)$ \\
\hline Number of Observations & & 1,071 & 1,179 \\
\hline
\end{tabular}

${ }^{1}$ Definitions of variables reported in Table 3. 
Table 3: Choice Models for Airline Security ${ }^{a}$

\begin{tabular}{|c|c|c|c|c|c|c|c|c|}
\hline \multirow[t]{2}{*}{$\begin{array}{c}\text { Choice } \\
\text { Determinants } \\
\end{array}$} & \multicolumn{4}{|c|}{ Gasoline Tax } & \multicolumn{4}{|c|}{ Income Tax } \\
\hline & (1) & (2) & (3) & (4) & (1) & $(2)$ & (3) & (4) \\
\hline Price & $\begin{array}{l}-.0026 \\
(-6.51)\end{array}$ & $\begin{array}{l}-.0026 \\
(-6.51)\end{array}$ & & & $\begin{array}{l}-.0083 \\
(-9.49)\end{array}$ & $\begin{array}{l}-.0083 \\
(-9.49)\end{array}$ & & \\
\hline Price*INC1 & & & $\begin{array}{l}-.0040 \\
(-4.28)\end{array}$ & & & & $\begin{array}{l}-.0101 \\
(-6.92)\end{array}$ & \\
\hline Price*INC1*RTOL & & & & $\begin{array}{l}-.0010 \\
(-0.48)\end{array}$ & & & & $\begin{array}{l}.0049 \\
(2.07)\end{array}$ \\
\hline Price*INC2 & & & $\begin{array}{l}-.0028 \\
(-4.21)\end{array}$ & & & & $\begin{array}{l}-.0098 \\
(-7.34)\end{array}$ & \\
\hline Price*INC2*RTOL & & & & $\begin{array}{l}.0006 \\
(0.54)\end{array}$ & & & & $\begin{array}{l}-.0007 \\
(-0.29)\end{array}$ \\
\hline Price*INC3 & & & $\begin{array}{l}-.0023 \\
(-3.99)\end{array}$ & & & & $\begin{array}{l}-.0046 \\
(-3.22)\end{array}$ & \\
\hline Price*INC3*RTOL & & & & $\begin{array}{l}.0007 \\
(0.66)\end{array}$ & & & & $\begin{array}{l}.0018 \\
(0.71)\end{array}$ \\
\hline Price*INC4 & & & $\begin{array}{l}-.0015 \\
(-1.59)\end{array}$ & & & & $\begin{array}{l}-.0070 \\
(-2.22)\end{array}$ & \\
\hline Price*INC4*RTOL & & & & $\begin{array}{l}.0013 \\
(0.54)\end{array}$ & & & & $\begin{array}{l}-.0014 \\
(-0.24)\end{array}$ \\
\hline Time & $\begin{array}{l}-.0073 \\
(-2.45)\end{array}$ & $\begin{array}{l}.0070 \\
(0.96)\end{array}$ & $\begin{array}{l}.0160 \\
(1.85)\end{array}$ & & $\begin{array}{l}-.0113 \\
(-3.95)\end{array}$ & $\begin{array}{l}-.0072 \\
(-1.12)\end{array}$ & $\begin{array}{l}.0017 \\
(0.23)\end{array}$ & \\
\hline Time* fly a lot & & & $\begin{array}{l}-.0126 \\
(-2.04)\end{array}$ & $\begin{array}{l}-.006 \\
(-0.87)\end{array}$ & & & $\begin{array}{l}-.0117 \\
(-2.19)\end{array}$ & $\begin{array}{c}.011 \\
(1.58)\end{array}$ \\
\hline $\begin{array}{l}\text { Time* } \\
\text { Mills }\end{array}$ & & $\begin{array}{l}-.0346 \\
(-2.15)\end{array}$ & $\begin{array}{l}-.0331 \\
(-2.07)\end{array}$ & $\begin{array}{l}-.036 \\
(-2.18)\end{array}$ & & $\begin{array}{l}-.0101 \\
(-0.71)\end{array}$ & $\begin{array}{l}-.0098 \\
(-0.68)\end{array}$ & $\begin{array}{l}-.014 \\
(-0.96)\end{array}$ \\
\hline $\begin{array}{l}\text { Laser Jamming } \\
\text { System }\end{array}$ & $\begin{array}{c}.569 \\
(4.60)\end{array}$ & $\begin{array}{c}.575 \\
(4.64)\end{array}$ & $\begin{array}{c}603 \\
(4.84)\end{array}$ & & $\begin{array}{c}.823 \\
(6.90)\end{array}$ & $\begin{array}{c}.824 \\
(6.91)\end{array}$ & $\begin{array}{c}.832 \\
(6.95)\end{array}$ & \\
\hline Laser*Flyalot & & & & $\begin{array}{l}-.266 \\
(-0.97)\end{array}$ & & & & $\begin{array}{l}-.907 \\
(-3.45)\end{array}$ \\
\hline Laser*Security & & & & $\begin{array}{c}.490 \\
(1.51) \\
\end{array}$ & & & & $\begin{array}{l}1.374 \\
(4.54)\end{array}$ \\
\hline $\begin{array}{c}\text { Pilot } \\
\text { Training }\end{array}$ & $\begin{array}{c}344 \\
(2.84)\end{array}$ & $\begin{array}{c}349 \\
(2.88)\end{array}$ & $\begin{array}{c}.372 \\
(3.06)\end{array}$ & & $\begin{array}{c}529 \\
(4.68)\end{array}$ & $\begin{array}{c}529 \\
(4.68)\end{array}$ & $\begin{array}{c}535 \\
(4.72)\end{array}$ & \\
\hline $\begin{array}{c}\text { Pilot Training } \\
\text { *Flyalot }\end{array}$ & & & & $\begin{array}{l}-.290 \\
(-1.01) \\
\end{array}$ & & & & $\begin{array}{l}-.977 \\
(-3.59)\end{array}$ \\
\hline $\begin{array}{c}\text { Pilot } \\
\text { Training*Security }\end{array}$ & & & & $\begin{array}{c}.652 \\
(1.96)\end{array}$ & & & & $\begin{array}{l}1.263 \\
(3.84)\end{array}$ \\
\hline Patrol & $\begin{array}{c}.057 \\
(0.40) \\
\end{array}$ & $\begin{array}{c}.060 \\
(0.43)\end{array}$ & $\begin{array}{c}.089 \\
(0.62) \\
\end{array}$ & & $\begin{array}{c}.553 \\
(4.01) \\
\end{array}$ & $\begin{array}{l}1.554 \\
(4.01)\end{array}$ & $\begin{array}{c}.558 \\
(4.04)\end{array}$ & \\
\hline Patrol*Flyalot & & & & $\begin{array}{c}.018 \\
(0.06)\end{array}$ & & & & $\begin{array}{l}-.357 \\
(-1.24)\end{array}$ \\
\hline Patrol*Security & & & & $\begin{array}{c}.907 \\
(2.38)\end{array}$ & & & & $\begin{array}{l}1.029 \\
(3.14)\end{array}$ \\
\hline Pseudo $\mathrm{R}^{2}$ & .023 & .0246 & .0273 & & .0271 & .0273 & .0311 & \\
\hline
\end{tabular}

\footnotetext{
${ }^{\mathrm{a}}$ The numbers in parentheses below the estimated coefficients are the Z-statistics for the null hypothesis of no association.
} 
Table 4: Estimated Willingness to Pay for Security of Commercial Airlines to Terror Related Threats ${ }^{a}$

\begin{tabular}{|c|c|c|c|c|c|c|}
\hline \multirow{3}{*}{ Plan } & \multicolumn{6}{|c|}{ Model $^{+}$} \\
\hline & \multirow{2}{*}{ (1) } & \multirow{2}{*}{$(2)$} & \multicolumn{4}{|c|}{ (3) } \\
\hline & & & INC1 & INC2 & INC3 & INC4 \\
\hline \multicolumn{7}{|l|}{ A. Gas Tax } \\
\hline $\begin{array}{l}\text { Jamming Device for } \\
\text { Infrared Missiles } \\
\text { (Man Pad) }\end{array}$ & $\begin{array}{l}220.8 \\
(4.90)\end{array}$ & $\begin{array}{l}221.8 \\
(4.93)\end{array}$ & $\begin{array}{l}149.0 \\
(3.72)\end{array}$ & $\begin{array}{l}210.1 \\
(3.80)\end{array}$ & $\begin{array}{c}266 \\
(3.54)\end{array}$ & $\begin{array}{l}394.8 \\
(1.55)\end{array}$ \\
\hline $\begin{array}{l}\text { Fuel Tank Protection } \\
\text { and Pilot Training }\end{array}$ & $\begin{array}{l}133.4 \\
(2.93)\end{array}$ & $\begin{array}{l}134.8 \\
(2.97)\end{array}$ & $\begin{array}{c}91.9 \\
(2.73)\end{array}$ & $\begin{array}{l}129.6 \\
(2.70)\end{array}$ & $\begin{array}{l}164.1 \\
(2.67)\end{array}$ & $\begin{array}{l}243.5 \\
(1.45)\end{array}$ \\
\hline Increased Patrols & $\begin{array}{c}22.2 \\
(0.41)\end{array}$ & $\begin{array}{c}23.4 \\
(0.44)\end{array}$ & $\begin{array}{c}21.9 \\
(0.64)\end{array}$ & $\begin{array}{c}30.9 \\
(0.64)\end{array}$ & $\begin{array}{c}39.1 \\
(0.65)\end{array}$ & $\begin{array}{c}58.1 \\
(0.61)\end{array}$ \\
\hline \multicolumn{7}{|l|}{ B. Income Tax } \\
\hline $\begin{array}{l}\text { Jamming Device for } \\
\text { Infrared Missiles }\end{array}$ & $\begin{array}{c}99.6 \\
(7.66)\end{array}$ & $\begin{array}{c}99.7 \\
(7.66)\end{array}$ & $\begin{array}{r}82.3 \\
(6.02) \\
\end{array}$ & $\begin{array}{r}84.5 \\
(6.09) \\
\end{array}$ & $\begin{array}{l}181.9 \\
(3.32) \\
\end{array}$ & $\begin{array}{l}119.4 \\
(2.17)\end{array}$ \\
\hline $\begin{array}{l}\text { Fuel Tank Protection } \\
\text { and Pilot Training }\end{array}$ & $\begin{array}{c}64.0 \\
(4.81)\end{array}$ & $\begin{array}{c}64.0 \\
(4.81)\end{array}$ & $\begin{array}{c}52.9 \\
(4.28)\end{array}$ & $\begin{array}{c}54.3 \\
(4.37)\end{array}$ & $\begin{array}{l}117.0 \\
(2.96)\end{array}$ & $\begin{array}{l}76.8 \\
(2.03)\end{array}$ \\
\hline Increased Patrols & $\begin{array}{c}66.9 \\
(4.89)\end{array}$ & $\begin{array}{c}66.9 \\
(4.89)\end{array}$ & $\begin{array}{c}55.2 \\
(4.20)\end{array}$ & $\begin{array}{c}56.7 \\
(4.24)\end{array}$ & $\begin{array}{l}122.1 \\
(3.26)\end{array}$ & $\begin{array}{c}80.1 \\
(2.07)\end{array}$ \\
\hline
\end{tabular}

${ }^{a}$ The numbers in parentheses are the asymptotic $Z$ statistics for a test of zero marginal willingness to pay.

${ }^{+}$The model numbers refer to the models in Table 3. 
Table 5: Plan Costs Assigned by Payment Vehicle

\begin{tabular}{|cccc|}
\hline & Jamming Device & $\begin{array}{c}\text { Fuel Tank \& } \\
\text { Training }\end{array}$ & Patrol \\
\hline Gasoline Tax & & & \\
\hline Range & $2.5-1192$ & $2.6-1164$ & $2.4-2053$ \\
\hline Median & 57.5 & 40.2 & 83.4 \\
\hline Mean & 107.4 & 75.5 & 129.8 \\
\hline Income Tax & & & $8-120$ \\
\hline Range & $8-120$ & $8-120$ & 50 \\
\hline Median & 50 & 15 & 60.4 \\
\hline Mean & 48.8 & 36.2 & \\
\hline
\end{tabular}


Table 6: Respondents' Decisions About Plans: Confirming Attitudes

I. Response: I didn't vote for either plan because I think my income taxes are (the price of gasoline is) already too high. $\left(\chi^{2}(1)=9.31, p\right.$-value $=$ $0.003)$

\begin{tabular}{|lccc|}
\hline Payment Vehicle & No & Yes & Total \\
\hline Gasoline Tax & 833 & 225 & 1058 \\
& $(78.7)$ & $(21.3)$ & \\
\hline Income Tax & 973 & 189 & 1162 \\
& $(83.7)$ & $(17.3)$ & \\
\hline
\end{tabular}

${ }^{a}$ Numbers in parentheses are percentages. Responses are asked of each respondent with each payment vehicle at the end of the sequence of two questions so they relate to the second of the questions asked.

II. Question: Are you very concerned, somewhat concerned, or not at all concerned about the risks of missiles being fired at airplanes inside the U.S.?

\begin{tabular}{|c|c|c|c|c|c|}
\hline $\begin{array}{l}\text { Pick Plan Because } \\
\text { Worried }\end{array}$ & Total & Don't Know & $\begin{array}{c}\text { Very } \\
\text { Concerned }\end{array}$ & $\begin{array}{l}\text { Somewhat } \\
\text { Concerned }\end{array}$ & $\begin{array}{l}\text { Not at all } \\
\text { Concerned }\end{array}$ \\
\hline \multicolumn{6}{|c|}{ Gasoline $\operatorname{Tax}\left(\chi^{2}(3)=111.89, \mathrm{p}\right.$-value $\left.=0.00\right)$} \\
\hline No & 798 & 2 & 109 & 469 & 218 \\
\hline Yes & 260 & 0 & 100 & 150 & 10 \\
\hline \multicolumn{6}{|c|}{ Income Tax $\left(\chi^{2}(3)=113.48, p\right.$-value $\left.=0.00\right)$} \\
\hline No & 852 & 2 & 130 & 501 & 219 \\
\hline Yes & 310 & 1 & 124 & 170 & 15 \\
\hline
\end{tabular}

III. Question: I don't think the plan to install jamming devices on planes to detect and divert missiles will work very well

A. Jamming devices $*\left(\chi^{2}=2.984, p\right.$-value $\left.=0.08\right)$

\begin{tabular}{|c|c|c|c|}
\hline Payment Vehicle & No & Yes & Total \\
\hline Gasoline Tax & 936 & 122 & 1058 \\
& $(88.5)$ & $(11.5)$ & 1162 \\
\hline Income Tax & 1054 & 108 & \\
& $(90.7)$ & $(9.29)$ & \\
\hline
\end{tabular}

* "No" indicates respondent failed to check verbatim indicating he/she felt the plan would not work. 


\section{Appendix A: The Knowledge Networks Web-Panel}

The current Knowledge Networks (KN) panel consists of approximately 40,000 adults actively participating in research. Beginning recruitment in 1999, Knowledge Networks (KN) has established the first online research panel based on probability sampling that covers both the online and offline populations in the U.S. The panel members are randomly recruited by telephone and households are provided with access to the Internet and hardware if needed. Unlike other Internet research that covers only individuals with Internet access who volunteer for research, KN surveys are based on a sampling frame that includes both listed and unlisted phone numbers, and is not limited to current Web users or computer owners. Panelists are selected by chance to join the panel; unselected volunteers are not able to join the KN panel.

KN initially selects households using random digit dialing (RDD) sampling methodology. Once a household is contacted by phone and household members recruited to the panel by obtaining their email address or setting up e-mail addresses, panel members are sent surveys over the Internet using email (instead of by phone or mail). This permits surveys to be fielded quickly and economically, and also facilitates longitudinal research. In addition, this approach reduces the burden placed on respondents, since e-mail notification is less obtrusive than telephone calls, and allows research subjects to participate in research when it is convenient for them. KN's panel recruitment methodology uses the quality standards established by selected RDD surveys conducted for the Federal Government.

A number of studies have compared KN and other web-based surveys with other modes of administration. Overall some differences in the responses to web-based, mail and telephone surveys have been documented, but in some cases the web-based survey offers an improvement over telephone surveys in eliciting more accurate responses (Berrens et al. 2003, Krosnick and Chang 2001, and Dennis et al. 2005). Dennis et al. (2005) found mode effects, but only "sparse" evidence for differences due to sample selection (sample origin) comparing a web survey of KN panel members, a telephone survey of active KN panel members, and a telephone survey of persons who refused to join the KN panel and 
members who did not respond to the web survey. Berrens et al. (2003) and Krosnick and Chang (2001) investigate mode effects comparing KN's panel with an RDD telephone survey and the Harris Interactive internet panel (members of this panel volunteer to join). Both papers report some statistically significant differences across the three samples, although the authors considered the differences to be modest in size. The Berrens et al. survey asked questions about climate change and included a discrete choice contingent valuation survey question about the household's willingness to pay for Senate ratification of the Kyoto Protocol. The authors concluded comparing all four samples that:

“...across all four samples, the analyst would make the same policy inference for the validity test-the probability of voting yes on the referendum is significantly and inversely related to the bid price (or cost) of the policy." (p. 20)

While the models were estimated with logit and thus measure normalized coefficients in each model (i.e. the parameter relative to a scale parameter), the coefficient estimates for the cost term are remarkably stable-ranging from -.88 (RDD Telephone) to -.80 (Harris Interactive). Berrens et al. conclude that "With appropriate weighting, samples from these panels are sufficiently representative of the U.S. population to be reasonable alternatives in many applications to samples gathered through RDD telephone surveys" (p. 1).

In addition, recent studies have investigated the potential for nonresponse bias in SP willingness to pay surveys administered through KN. Studies that investigated various sources of non-response bias have found some evidence of sample selection, but little evidence of bias in willingness to pay and the differences that have been found were judged to be small (Banzahf et al. 2004, Viscusi et al. 2004, Cameron and DeShazo 2004). Cameron and DeShazo [2005] investigated the possible selection effects resulting from KN's recruiting process on attitudes toward government regulation of environment, health and safety risks. The authors began their analysis using the full RDD sample contacted by KN between 1999 and May 1, 2003, to join the KN web panel and matched the telephone numbers to census tracts (for telephone numbers without a matching address, the authors match the number of the most likely census tract). Looking at the complete set of census tracts from which the KN panel was recruited, the authors found that Census tract-level factor scores summarizing year 2000 Presidential 
voting patterns, economic and demographic attributes of the households influence the likelihood that individuals join the KN panel. However, accounting for selection effects associated with joining the KN panel and completing their survey, they cannot reject the null hypothesis of no error correlation between the selection probability model's error and attitudes toward government involvement in social regulations measured as part of their survey (attitudes toward government regulation was measured by the question: "People have different ideas about what their government should be doing. How involved do you think the government should be in regulating environmental, health and safety hazards?" The answer options ranged from $1=$ minimally involved up to $7=$ heavily involved). 